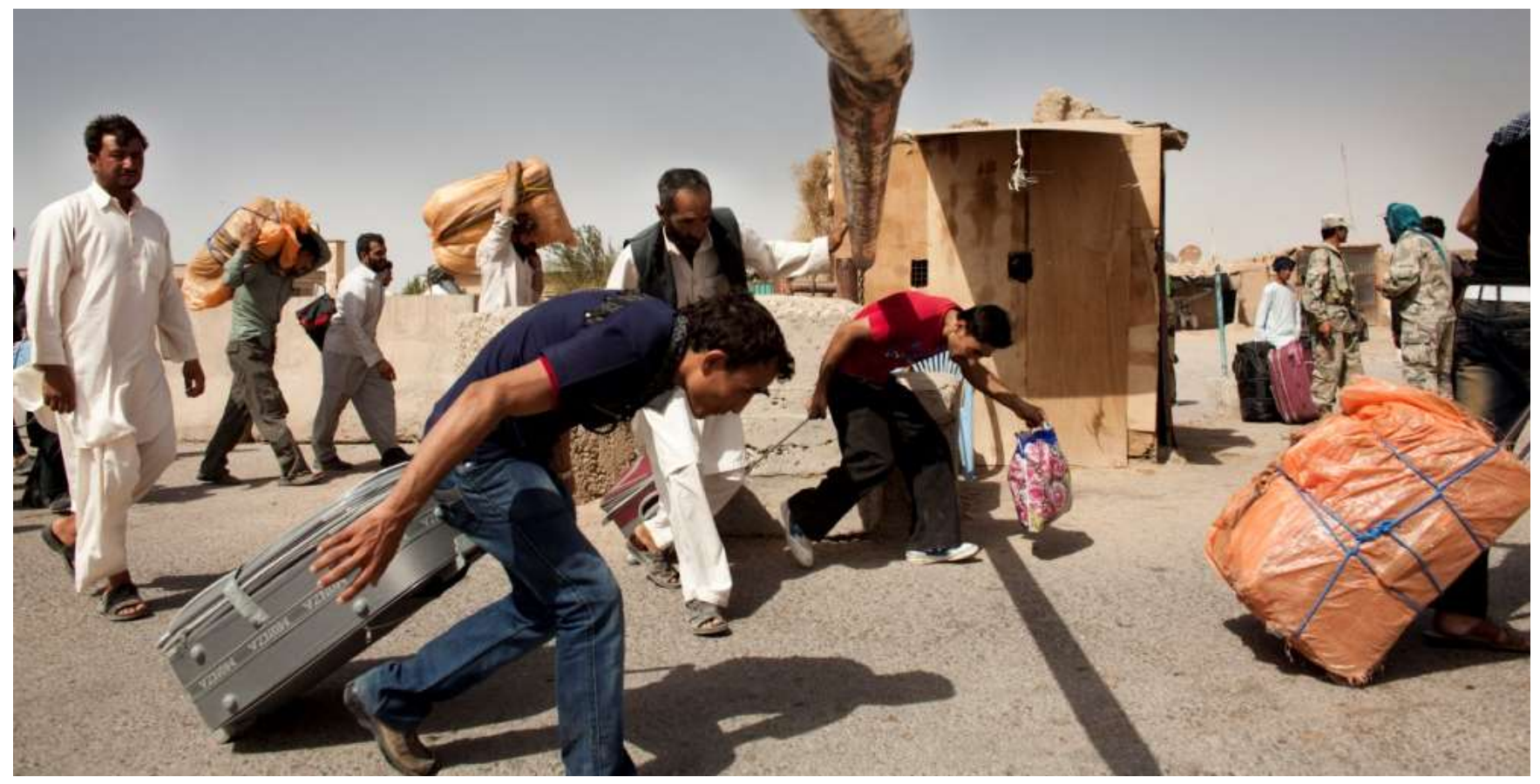

Afghans returning from Iran, at the Islam Qala border crossing with Herat province. Photo: @ Joel van Houdt

\title{
RETURNING TO FRAGILITY \\ Exploring the link between conflict and returnees in Afghanistan
}

Huge numbers of people are returning to Afghanistan - more than two million since 2015 - while the country is still highly fragile, with ongoing fighting and internal displacement in many areas and high levels of poverty. Oxfam's field research in Herat, Kabul, Kunduz and Nangarhar finds that for as long as these conditions do not improve, a safe and dignified return cannot be guaranteed, and forced returns remain irresponsible. With more people returning on a daily basis, tensions are likely to grow and pressure on scarce resources will increase, exacerbating inequalities in this unstable and fragile country. Sending Afghans back to volatile areas will likely result only in more displacement and fragility. 
In the past few years, Afghanistan has witnessed unprecedented numbers of returnees, mainly from Iran and Pakistan and to a lesser extent from Europe. Since the beginning of 2015, more than two million Afghans have returned, many involuntarily as a result of changing domestic policies in the countries to which they fled or migrated.

Oxfam in Afghanistan's field research in Herat, Kabul, Kunduz and Nangarhar finds that, for as long as current conditions do not improve in the country, forced returns remain dangerous, as safety and dignity cannot be guaranteed. People who are unable to return to areas in which they own land - or can be supported by their family or community - often end up in situations of internal displacement, increasing the country's fragility. The capacity to absorb returnees and meet humanitarian needs is limited. This fragile situation will remain unchanged unless the root causes of conflict are addressed in a sustainable way.

In the meantime, more Afghans are returning every day to a situation of protracted conflict that perpetuates poverty and instability. After 2016 was one of the deadliest years for civilian casualties, ${ }^{2}$ the first six months of 2017 saw a $23 \%$ increase in women casualties and a $9 \%$ increase in child deaths. ${ }^{3}$ As long as these fragile conditions persist, Afghans should not be forced to return to their country.

The ongoing conflict in Afghanistan is still causing displacement on a daily basis: by 2016, the total number of internally displaced people (IDPs) was approximately 1,553,000; between 1 January and 3 December 2017, an estimated additional 372,977 Afghans fled their homes. The conflict in Afghanistan therefore continues to be much more a driver of displacement and migration than vice versa.

There is very limited government capacity to address the proper reception and reintegration of returnees, and there is no clear government policy to cope with the corresponding humanitarian needs. This is especially problematic for women and children, who constitute the largest part of returnees.

Most attention has so far been devoted to the humanitarian and protection needs of returnees and the internally displaced, which represent a key challenge for the Afghan government and the international community. However, if the conflict dynamics of return are neglected, an already dire situation may become much worse. It is important to better understand how the return of Afghans is linked to possible causes of disputes and friction, as it represents an additional layer of potential conflict and fragility that could further destabilize a highly insecure and polarized Afghanistan.

This research shows that two factors are crucial to determining the scope of potential conflict: 1) absorption capacity at local level, which depends to a certain extent on support from extended family members or on assistance from the government or international agencies; and 2) the (social) adaptation or

\author{
'As ground \\ engagements \\ continued to cause \\ most civilian \\ casualties, suicide and \\ complex attacks, and \\ improvised explosive \\ devices (IEDs) took a \\ heavy toll on Afghan \\ civilians, with those \\ living in the provinces \\ of Kabul, Helmand, \\ Nangarhar, Kandahar, \\ and Faryab suffering \\ the heaviest losses" \\ UNAMA, Afghanistan \\ Protection of Civilians in Armed \\ Conflict Quarterly Report (12 \\ October 2017)
}


(re)integration capacity of returnees, whether in their communities of origin or in new areas where they wish to settle.

The majority of those forced to return from Iran and Pakistan were unregistered refugees, which means they did not receive official refugee status on arrival in the neighbouring countries. From Europe, those who are returning have been denied refugee status at the end of asylum procedures or given up on the process. The European dimension of this problem is only the tip of the iceberg: since the beginning of 2015, returnees from Europe account for only $0.6 \%(14,943)$ of the total $(2,316,558)$. While around 380,000 first-time asylum applicants from Afghanistan were registered in the European Union between January 2015 and June $2017,{ }^{4}$ the different, complex and lengthy procedures in member states make it highly unlikely that those with unsuccessful applications would be sent back to Afghanistan in large numbers at the same time.

The international principle of 'non-refoulement' (no expulsion) prohibits the return of anyone to a place where they would face a serious risk of persecution, torture or other ill-treatment, or a threat to life. However, some governments have argued in favour of an 'internal flight/protection alternative', claiming that if asylum seekers have protection options within their own country, they can be returned. ${ }^{6}$ In the case of Afghanistan, the highly volatile and unpredictable nature of the protracted conflict makes it impossible to know whether a city or region that is stable now will remain that way for any extended period of time. Under such conditions, it cannot reasonably be found that an Afghan person no longer has a fear of persecution or other serious violations upon return, regardless of the location. Also, the Afghan state is currently unable to protect its citizens in any part of the country, which means there are no safe havens within Afghanistan.

\section{MAIN FINDINGS FROM THE FIELD RESEARCH}

- The risk of secondary displacement: Internal displacement, due to conflict and lack of economic opportunities, continues to threaten communities and individuals. Returnees who receive inadequate support or end up in volatile areas may find themselves displaced for a second time.

- Limits to absorption capacity: Concerns are growing across the four provinces - Herat, Kabul, Kunduz and Nangarhar - that the labour market and local communities are unable to absorb more returnees until security and the economic situation improve.

- The importance of returning to the region of origin: Returnees who are unable or afraid to return to their region of origin are generally worse off than those who can. They tend to have fewer employment opportunities, and less access to land, patronage and support from families.

- The crucial support of family networks: The support of family networks is a crucial element in ensuring that (re)integration is successful, but it does not automatically make it sustainable.
'We have seen a year-on-year increase in civilian casualties which just demonstrates that civilians are the most affected by the war. ${ }^{5}$

Mark Bowden, former UN Humanitarian Coordinator in Afghanistan (February 2017) 
- The importance of access to land: Access to land allocated by the government or previously owned by the family enables re-integration. In contrast, returnee settlements make assistance easier, but at the expense of integration and the reinforcement of aid dependency.

- The significance of time to prepare for return: Afghans who were forcibly returned - or, for other reasons, had insufficient time to make arrangements for their return - are worse off than those who returned at the end of a more gradual process which allowed them to develop (re)integration strategies and coping mechanisms. 'Look and see' visits to plan for return were considered beneficial.

- Limited discrimination: In the four provinces surveyed - Herat, Kabul, Kunduz and Nangarhar - Afghan returnees are mostly perceived as part of society and do not suffer structural discrimination from host communities. This may change, however, especially when returnees settle in isolated groups rather than integrating.

- No evidence for a direct causal link between returnees and conflict, but clear links to a build-up of local friction and tension: While there is no measurable impact of returns on the overall security situation in Afghanistan, there have been reports of local fear, friction, tension and confrontations, mostly connected to competition over scarce resources such as land and employment opportunities.

\section{RECOMMENDATIONS}

\section{For the Afghan government:}

1. Do not promote returns until these can take place in safety and dignity into areas that are stable in the long term and sufficiently equipped to absorb arriving returnees.

2. Prioritize, as part of well-planned development programmes, returnees' access to land and basic social services, with a particular focus on access to education, for children and youth, and healthcare. This support should not be treated as a short-term emergency response, but rather as a longterm development approach aimed at benefiting all in the community.

3. Do not promote or accept any returns solely for political reasons. With parliamentary elections being planned for July 2018, there are concerns that some Afghan politicians may be promoting returns to increase their constituencies.

4. With countries hosting Afghans, stress the need for time and proper planning, including securing support from family members and/or host communities, before any returns are considered.

5. Do not accept any conditioning of foreign assistance and development cooperation on the acceptance of returnees from donor countries.

6. Add a conflict sensitivity analysis (including a gender analysis of conflict) to the adopted Policy Framework for IDPs and Returnees. In the Action Plan matrix, this can be done by adding a new column for reflections on linkages with possible friction, tension, disputes or conflict, and how these are addressed or mitigated. The Policy Framework includes just one short paragraph about the need to mitigate tensions (paragraph 15), which is 
currently limited to the relationship between returnees and host communities.

7. In line with the aforementioned conflict sensitivity analysis, develop an early warning mechanism with clear indicators for local friction, tension, disputes or conflicts, including those related to assistance, protection, reintegration and access to resources, housing and the labour market.

8. Improve coordination at operational level in the provinces, in line with increased coordination at the national level (especially the Executive Committee of IDPs and Returnees led by the CEO Office and supported by donor agencies, and the Policy Framework and Action Plan that were adopted).

\section{For the international community supporting the Afghan government:}

1. Do not treat support for return processes as a short-term emergency response, but rather as a development programme that needs to be well planned to meet short-, medium- and longer-term needs of returnees and host communities.

2. Honour current financial pledges, and increase funding to meet the humanitarian and development needs of returnees, internally displaced people and host communities. The UN Flash Appeal in September 2016 covered only $44.4 \%$ of total needs. ${ }^{7}$

3. Do not make funding for returnee support programmes or development cooperation in general conditional on the Government of Afghanistan signing returns agreements before conditions of safety, stability and dignity warrant them.

4. Increase support for:

- Continuing to meet returnees' emergency needs for cash, food, water, clothes, shelter and medical assistance after the limited initial support provided upon arrival;

- Development assistance focusing on access to education and longer-term livelihoods, and conflict-sensitive job creation programmes involving (re)integration and host communities with a special focus on women and female-headed households;

- Non-agricultural and urban livelihood opportunities for returnees, as they often have neither access to land nor the required skill sets for agricultural work, and tend to favour more lucrative urban and peri-urban possibilities;

- Cash-for-work programmes, with a particular focus on women, to increase access to livelihoods - structurally linked, where possible, to broader government public works programmes;

- Internally displaced people, in parallel to increased support for returnees, as they have particular needs and vulnerabilities and are often worse off than returnees.

5. Make sure that all support is based on needs. It is unacceptable that returnees from one country receive different treatment than those from another country if their needs are the same.

6. Support the International Organization for Migration (IOM) to extend its returnee monitoring programme beyond 12 months, with an increased focus on monitoring conditions for safe and dignified returns and sustainable reintegration. 
7. Complement short-term post-arrival and humanitarian support strategies with a long-term development strategy of supporting the government with more structural solutions including job creation and effective land allocation plans. More conflict-sensitive reconstruction efforts are required, with programming at local and national levels that reinforces the social contract (including through anti-corruption measures), reduces inequality, improves accountability and addresses the root causes and drivers of conflict in Afghanistan.

8. As part of both the short-term emergency support and longer-term development assistance, particularly invest in opportunities and mechanisms that can bring host communities and returnees together to increase mutual understanding, prevent tensions from arising and strengthen social cohesion.

9. Improve coordination among the international agencies involved in support to returnees, as well as between general development projects targeting host communities and those specifically targeting returnees. Friction can arise if the needs of host communities go unmet while returnees receive support in their areas.

10. Invest in more research and analysis to increase understanding about:

- The link between recurrence of conflict and the situation of returnees, internally displaced people and host communities. Such analysis can build on existing instruments such as the Returnee Resilience Measure Index (RRMI), developed by Samuel Hall, and research methodologies such as the Emergency Market Mapping and Analysis Toolkit; ${ }^{8}$

- Opportunities to prevent conflict by anticipating future pressure points such as food security and access to livelihoods, housing, jobs and education. Specific research should be carried out to assist the Afghan government with developing an early warning mechanism with clear indicators for local friction, tension, disputes or conflicts;

- Psychosocial effects of the return of Afghans, particularly for specific groups such as women, youth and ethnic minorities;

- Linkages between social tensions around displacement and drivers of recruitment into radicalization and violent extremism, which are among the fears expressed by host communities.

\section{For governments hosting Afghan nationals:}

1. Immediately stop forcibly returning people until conditions in Afghanistan are stable and sustainable, so that people can return in safety and dignity. Sending Afghans back to volatile areas, such as the high-return destinations Kunduz and Nangarhar, will likely result in more displacement and fragility.

2. Ensure any decisions on returns in the future are based on an individual, independent and periodical assessment of the specific conditions in Afghanistan, cognisant that returnees are not always able to return to their area of origin, and that returns to an alternative location may raise serious safety and protection concerns or result in pressure on local communities. 
3. Ensure that any future safe return procedures are linked to guaranteed (re)integration assistance and longer-term development support provided by host countries or third parties, based on the specific needs of returnees, going beyond treating support to returnees only as short-term emergency assistance.

Box 1: United Nations Refugee Agency (UNHCR)'s concept of returning in safety and with dignity ${ }^{9}$

Return in safety: A return which takes place under conditions of:

- Legal safety (such as amnesties or public assurances of personal safety, integrity, non-discrimination and freedom from fear of persecution or punishment upon return);

- Physical security (including protection from armed attacks, mine-free routes, violence, etc.);

- Material security (e.g. access to land or means of livelihood).

Return with dignity: A return which takes place with:

- Good treatment;

- Family members kept together;

- Full respect of and acceptance by national authorities;

- Full respect for the returnees' rights;

- No conditions attached to the process of returning. 
There has been considerable research ${ }^{10}$ in recent years about the return of people to Afghanistan and the levels of coercion and vulnerability involved, whether for the returnees themselves or for the host communities that receive them.

Less researched, however, are the conflict-related aspects of the returnee phenomenon. How does the return of large numbers of Afghan people impact the already volatile situation in Afghanistan? What are the consequences of the additional pressure created on scarce resources, limited government capacity and weak support infrastructure? This Oxfam briefing paper provides insight into how the return affects or causes local tension, friction and grievances, given the context of insecurity and instability to which returnees return.

This paper is the result of a combination of desk and field research. It is based on a review of situation reports from the International Organization for Migration (IOM) and UN Office for the Coordination of Humanitarian Affairs (UN OCHA), field assessment reports from organizations including the Danish Refugee Council (DRC), the Danish Demining Group (DDG), the Norwegian Refugee Council (NRC), Oxfam and Samuel Hall, as well as human rightsrelated reports from Amnesty International and Human Rights Watch.

The field research consisted of focus group meetings, key informant interviews with both government and civil society representatives, and individual interviews targeting both returnee populations and host communities in four provinces: Herat, Kabul, Kunduz and Nangarhar. In each province, about 100 semi-structured interviews took place with both returnees and host community members. These were not a scientific survey, but provided meaningful insight into the local perceptions of how conflict and the return of Afghans are related.

The field research was carried out by Oxfam between February and August 2017, with assistance of NRC, the Afghan Development Association (ADA) and the Peace Training and Research Organization (PTRO). For Nangarhar, this research also builds on the Emergency Market Mapping and Analysis (EMMA) that was conducted by Oxfam, with support from Assistance for Health, Education, and Development (AHEAD) between March and April 2017. ${ }^{11}$

The briefing paper addresses the situation in Afghanistan in relation to the huge number of returnees, with a focus on any potential tensions, grievances or disputes that may consequently arise. As such, it assesses the current reality in Afghanistan as well as possible future scenarios. It does not seek to blame specific countries or actors for causing the current situation, but this does not mean that the current situation and any future returns should be accepted without scrutiny. Whether returning voluntarily or involuntarily, Afghans have a right to a decent reception, a safe homecoming and reintegration in their communities. That means a careful assessment of the security situation should be combined with an evaluation of whether or not, for example, returnees can find jobs and their children can go to school. 


\section{INTRODUCTION}

The return of Afghans has received much less international attention than the arrival of Afghans to Europe, whether as refugees or economic migrants. Only recently has the focus of the debate shifted more towards the conditions inside Afghanistan, with the worsening security situation and the controversial ${ }^{13} \mathrm{EU}$ Joint Way Forward deal with Afghanistan in October 2016 to send back Afghan asylum seekers. In addition to growing insecurity, the combination of political instability, weak governance, economic stagnation, elite capture and persisting poverty has raised questions about whether Afghans can return to Afghanistan with safety and dignity. While this debate is necessary, the reality is that Afghans are already returning, both voluntarily and involuntarily, and in large numbers.

Figure 1 and Table 1 below show the estimated numbers of returnees since the beginning of 2015 , according to the three main source areas. The number of returnees coming from Europe is only a small fraction $(0.6 \%)$ of the total number of returnees.

Figure 1: Returnees to Afghanistan since 2015, percentages by source area
'The political and security situation in Afghanistan will also almost certainly deteriorate through $2018^{, 12}$

Dan Coats, US Director of National Intelligence (May 2017)

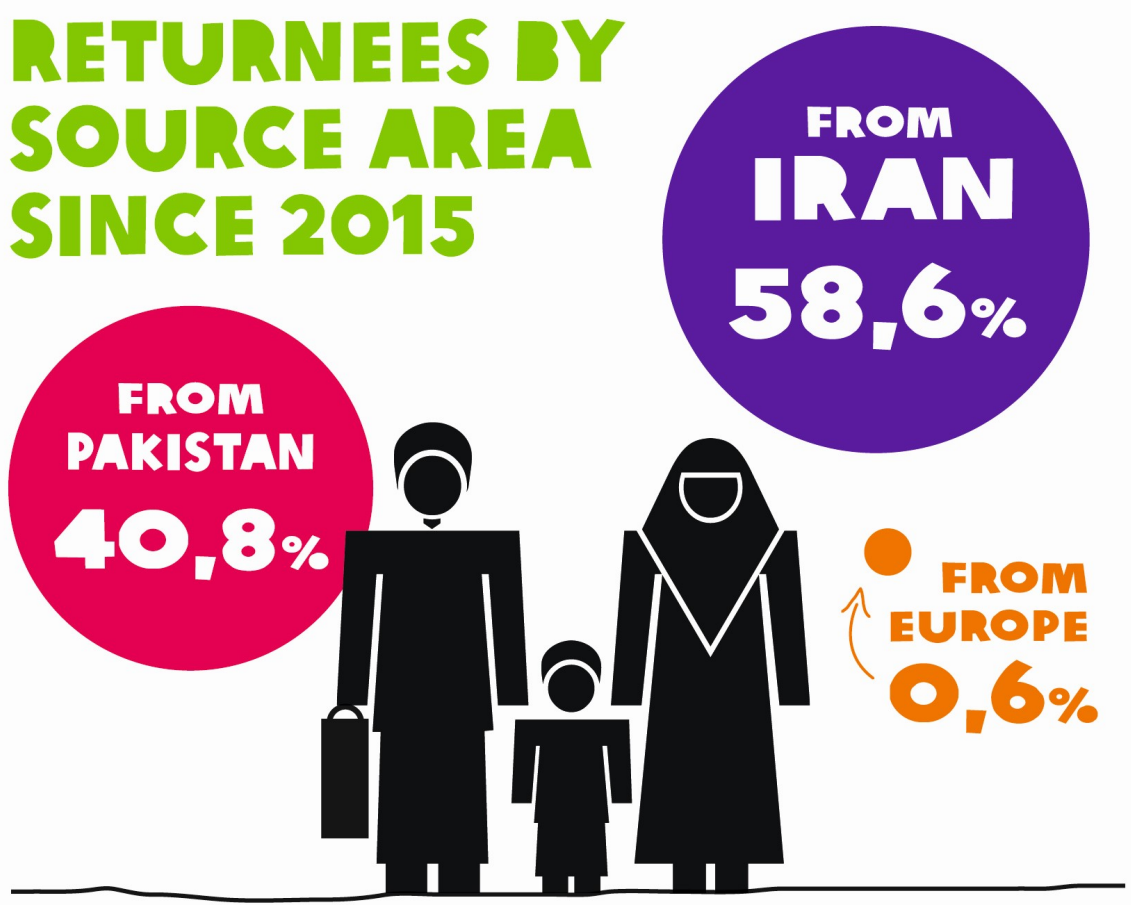


Table 1: Estimated number of returnees since January $2015^{14}$

\begin{tabular}{|c|c|c|c|c|}
\hline Year & Total returnees & From Iran & From Pakistan & From Europe \\
\hline 2015 & 684,257 & 510,395 & 170,572 & $\begin{array}{r}3,290(0.5 \% \text { of the } \\
\text { total })\end{array}$ \\
\hline 2016 & $1,067,935$ & 438,541 & 619,934 & $9,460(0.9 \%)$ \\
\hline 2017 & 564,366 & $407,986^{*}$ & **154,187 & ${ }^{* * *} 2,193(0.5 \%)$ \\
\hline Total & $2,316,558$ & $1,356,922$ & 944,693 & $14,943(0.7 \%)$ \\
\hline
\end{tabular}

${ }^{*}$ For Iran, the number of undocumented ${ }^{15}$ returnees in 2017 was recorded up to 25 November. The number of documented returnees (only a fraction of the total at 320 ) was recorded up to 3 June.

${ }^{* *}$ Recorded up to 25 November 2017.

${ }^{* * *}$ Recorded until the end of June 2017.

The number of people sent back or voluntarily returning since 2015 is astonishing, and will likely continue to grow. Iran initially planned to send back 600,000 Afghans by the end of 2017 , although this target may have been reduced. ${ }^{16}$ Pakistan revealed a plan in November 2015 to send back a total of 1.5 million Afghans before the end of $2017 .{ }^{17}$ It is not clear how many Afghans may return from Europe. However, if from the 380,000 first-time asylum applicants from Afghanistan registered in the European Union between January 2015 and June 2017 around 52\% would return (the percentage of unfavourable first-instance decisions registered in the second quarter of $2017^{18}$ ), this could mean an estimated 200,000 Afghans may return. This process, however, is expected to take many years given the complex procedures involved in both voluntary repatriation and deportation and the volatile security situation. In June 2017 , for example, Germany partly suspended returns following a significant attack in Kabul. ${ }^{19}$

The principle of non-refoulement (no expulsion) prohibits the return of anyone to a place where they would face a serious risk of persecution, torture or other ill-treatment, or a threat to life. In recent years, some governments have argued in favour of an 'internal flight/protection alternative,' claiming that asylum seekers may have protection options elsewhere within their own country, even if they are in danger in their specific home region. ${ }^{20}$ In the European Union, Article 8(1) of Council Directive 2004/83/EC ('the Qualification Directive') states that Member States 'may' refuse protection to an applicant if they consider that there is a part of the country of origin where the applicant would not be subjected to persecution or serious harm and the applicant 'can be reasonably expected to stay' in that area. ${ }^{21}$

In Afghanistan, however, the highly volatile and unpredictable nature of the protracted conflict makes it impossible to know whether a city or region that is stable now will remain that way for long. Under such conditions, it cannot reasonably be found that an Afghan person no longer has a fear of persecution or other serious violations upon return, regardless of the location. 
Although it matters where the returnees are sent back from - for example, in terms of the support packages ${ }^{22}$ they might receive - it is even more important to focus on what they come back to. The situation in Afghanistan has deteriorated in recent years, not only in terms of security but also human development, from inequality of schooling to unemployment. ${ }^{23}$ Poverty levels have not significantly changed since 2001 despite development efforts, with around $36 \%$ of the population living below the poverty line.${ }^{24} \mathrm{UN}$ OCHA initially estimated that 9.3 million Afghans would need humanitarian assistance during 2017, though this was reduced to 7.4 million in the mid-year review of the Humanitarian Response Plan $2017 .{ }^{25}$ Despite these needs, there is a funding gap of $\$ 248 m$ (roughly $€ 210 \mathrm{~m}$ ) in UNHCR's financial requirements for assistance in Afghanistan, Iran and Pakistan. ${ }^{26}$

The following sections detail why forced returns remain dangerous, and the safety and dignity of returnees cannot be guaranteed. If people are unable to return to areas in which they have community or family ties, or cannot plan their return through a gradual process, they can be condemned to living in fragile and precarious conditions which are directly connected to their internal displacement. 


\section{LINKING RETURNEES WITH CONFLICT}

Returnees are returning to fragility. But is their return also a contributing factor to fragility - and possibly even conflict - in the form of additional friction, grievances or disputes? An important part of the answer to that question is whether Afghanistan's returnee absorption capacity, currently relying to a large extent on the self-regulatory system of social and family networks as well as international support, can withstand more people coming back.

Only a few reports have assessed the conflict-related dynamics of the return. In February 2017, Human Rights Watch ${ }^{28}$ reported that some publications have particularly highlighted the 'destabilizing effects of increasing population pressure on limited local resources' as a cause of more instability. ${ }^{29}$ Other documents have suggested that 'unprepared returns without adequate prospects for full and effective reintegration can (...) induce tensions and prompt resort to negative coping strategies, including radicalization (...) ${ }^{30}$ Part of this assessment is the assumption that frustrations can arise when returnees cannot find livelihoods or are forced to rely on casual labour.

There are two problems with such assessments. Firstly, they are not clear about how exactly the causal links - direct or indirect - between returnees and conflict may work in practice. Secondly, they single out the returnee phenomenon, while many other actors and factors play a role in potentially increasing tension, instability or conflict.

This report provides a first step towards better understanding some of the linkages between the returnee phenomenon and conflict. At first glance, the idea of Afghans 'returning home' may not sound like something that could create conflict. However, returnees have often been away for a long time; they might never even have been in Afghanistan before. Previous conflicts in Afghanistan, from the 1980s Soviet invasion to the civil war in the early 1990s and the rise of the Taliban in the mid-1990s, have resulted in several waves of displacement, and Afghan refugees living for decades in foreign countries.

In this time, the situation in their communities of origin may have changed considerably. This presents a first set of potential causes of friction. Returnees may find that their properties no longer exist, or have been confiscated by others. Returnees may have developed different habits, norms and values during their long stay abroad through exposure to a more liberal culture, increasing the challenge of integration within host communities, which is perceived as a difficult process but a crucial way to avoid or resolve friction.

If returnees are unwilling or unable to return to or stay in their communities of origin, or no longer have a home there, they will become newcomers in other often urban - communities. This is a second set of potential causes of friction. Returnees can be considered outsiders or discriminated against, whether because of their returnee status or, for example, because they are from a different ethnic or tribal group than the majority of the host community.
'Thousands of Afghan families have been reduced to an ambiguous and transitory existence, as they continue to use mobility as a coping mechanism to manage conflict, natural disaster and livelihood risks. ${ }^{27}$

UN OCHA Humanitarian Response Plan 2017 
However, there are not necessarily more tension or disputes if returnees belong to different ethnic groups or have an ethnicity different from the host community. This is suggested by the Community Safety Survey of DDG Afghanistan; although it found that Afghans living in settlements experienced fewer disputes if they are from similar provinces, and it found more reports of disputes in ethnically homogenous communities. ${ }^{31}$

In both cases, returnees put additional pressure on local resources, which may be scarce, opening up many possibilities for local tensions. The current scale of the returnee phenomenon in Afghanistan often puts a heavy burden on available food, housing and jobs in local communities, whether rural or urban. If this results in declining standards of living or - as, unfortunately, is still often the case in Afghanistan - more poverty, tensions can easily arise. For the moment, however, most disputes in Afghan communities are not about returnees, but part of a broader pattern of conflict in Afghanistan. As Marie S. Huber and Mateja Zupancic write in the Community Safety Survey of DDG: 'Disputes over land, family disputes, and tribal rifts are common in Afghanistan. The displacement context adds a number of potential triggers for altercations, such as conflict over resources or challenges with the host community.'32

The present research shows that two factors are crucial to determine the scope of potential conflict: 1) the absorption capacity at local level, which depends to a certain extent on support from extended family members or on assistance from the government or international agencies; and 2) the (social) adaptation or (re)integration capacity of returnees, whether in their communities of origin or in new areas where they wish or need to settle because of protracted displacement.

Absorption capacity is currently being maintained by often-improvised family arrangements and external humanitarian assistance, which means the root causes of fragility are not being addressed: more conflict can easily arise when this patched-up support structure falls apart. Host community or extended family support may be unsustainable or cause friction between family and community members. Similarly, humanitarian assistance may not continue perpetually and may not be available in certain areas.

Lack of social adaptation and (re)integration may be another cause of future conflict. When returnees are socially or physically isolated from host communities, this can also limit their political participation and their engagement with local authorities. Some groups may not benefit at all from local government structures, which can increase grievances and friction at the local level. 


\section{THE AFGHAN CONTEXT}

The return of people brings myriad challenges to Afghanistan. Widespread corruption, ${ }^{34}$ political instability ${ }^{35}$ and lack of capacity hamper an effective government response in the face of increased conflict and an increased number of internally displaced people and returnees. The needs of returnees cannot be isolated from the huge number of internally displaced people who also require assistance and who compete for limited resources. By 2016, approximately $1,553,000$ people were internally displaced in Afghanistan. ${ }^{36}$ In the first half of 2017, around 159,000 more Afghans fled their homes due to conflict. ${ }^{37}$ By 3 December 2017, this number had more than doubled, to $372,977 .{ }^{38}$ From the interviews and focus group discussions, the picture emerges that internally displaced Afghans generally face more risks and vulnerabilities than returnees.
'(...) Afghanistan is not in a post-conflict situation (...) but a country undergoing a conflict that shows few signs of abating.

António Guterres, UN Secretary General (August 2017)

\section{Figure 2: Conflict severity map overlaid with the presence of IDPs and}

returnees.

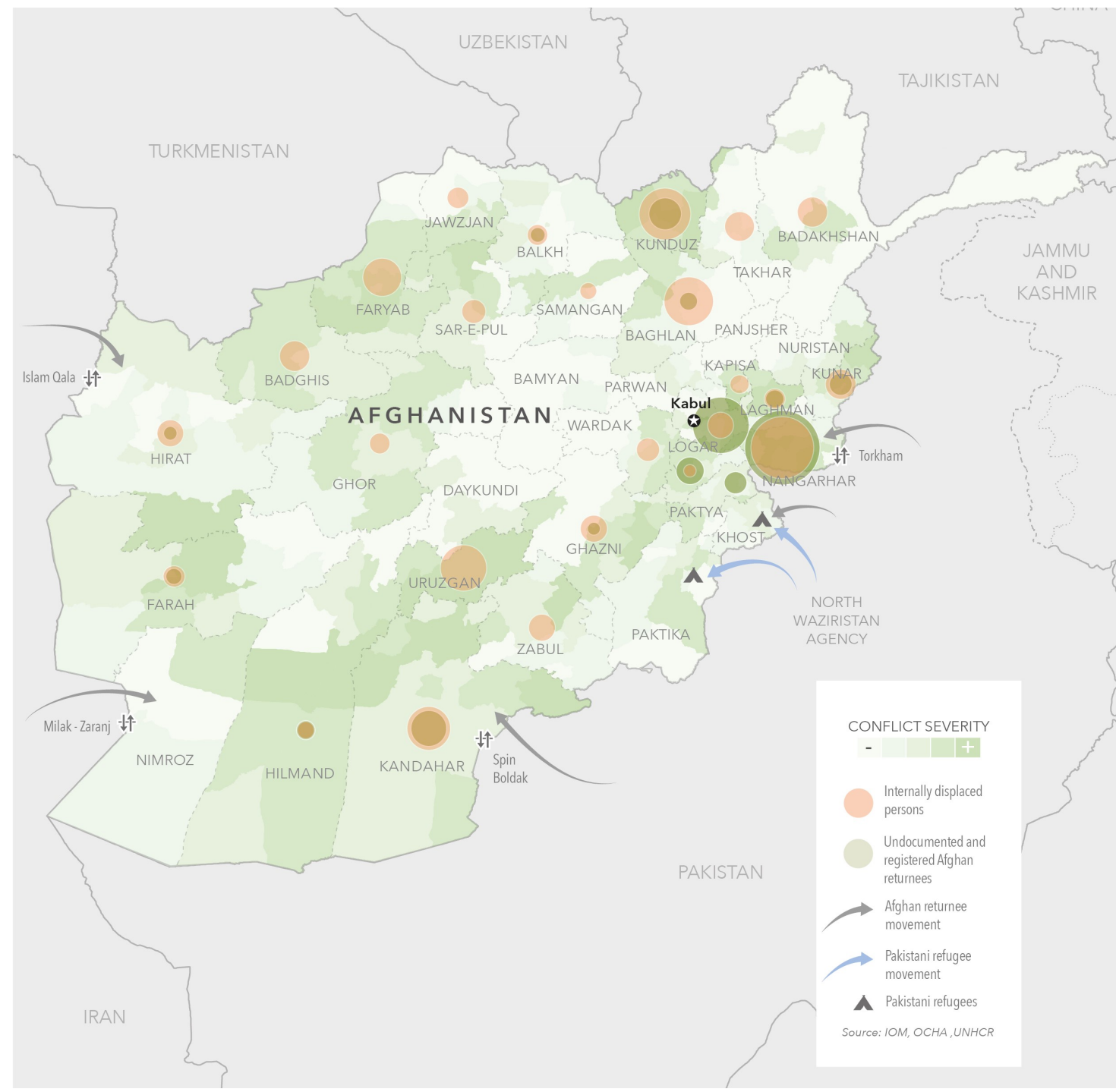


Based on the ongoing violence and increasing civilian casualties, organizations such as Amnesty and Pro Asyl have claimed that conditions are not safe for return right now. ${ }^{40}$ Amnesty has recently called for a 'moratorium on all returns to Afghanistan, until they can take place in safety and dignity. ${ }^{41}$ Oxfam agrees with this call. The German government temporarily halted deportations to Afghanistan in early June 2017, following one of the biggest attacks in Kabul; but Chancellor Merkel also stated that this does not represent a general halt of deportation procedures for Afghans denied asylum in Germany. ${ }^{42}$ The security situation is undoubtedly increasing challenges for some Afghans returning, while also being an important push factor for Afghans leaving the country.

There is very limited government capacity to address the proper reception and reintegration of returnees, and there is no clear government policy to cope with the corresponding humanitarian and development needs. ${ }^{43}$ This is especially problematic for women and children, who constitute a substantial part of returnees: $81 \%$, for example, of registered returnees from Pakistan. ${ }^{44}$ Among those who returned from this country, women represent $52 \%$ of undocumented $^{45}$ returnees and $51 \%$ of Afghan refugee returnees in $2017 .{ }^{46}$ Research shows that $30 \%$ of returnees face challenges finding livelihood opportunities, while $18 \%$ have trouble accessing food in the areas where they end up. ${ }^{47}$ There is neither a short- nor a long-term strategy for emergencies that may result from the ongoing return - which, for the moment, has no end in sight.

While the Afghan government receives assistance from international donors, international institutions such as IOM and UNHCR, and international NGOs, there is still too little coordination among the agencies involved in returnee support. IOM has put in place a registration system along the borders to register returnees so that they can be better tracked and assisted along their journey. However, IOM can track returnees for only twelve months, and there seems to be no strategy in place to use the data they collect for practical purposes such as vulnerability analysis, increasing assistance or protection.

While IOM's support is mostly short-term post-arrival assistance, a study commissioned by IOM defined conditions that should be in place for sustainable reintegration to take place. Summarized in Box 2, they can be considered the conditions that will also decrease possibilities for tension, grievances and conflict to arise.
'The human cost of this ugly war in Afghanistan - loss of life, destruction and immense suffering - is far too high $^{, 39}$

Tadamichi Yamamoto, Head of UNAMA mission (July 2017) 
Box 2: IOM study's conditions for sustainable reintegration of returnees ${ }^{48}$

- Involvement and active participation of the returnee in his/her return and reintegration process;

- A stable socioeconomic environment that provides income generation opportunities;

- Mitigation of possible security risks, especially if these were the reason for migrating in the first place;

- Psychosocial support to adapt to the new reality, define one's role in the community and ensure psychosocial stability;

- Sufficient time for the returnee to process the migration experience through a follow-up during the first 12 months upon arrival;

- Adequate skills training and financial support to empower the returnee to develop and implement a livelihood strategy;

- Support for the re-establishment of social networks by involving family members, friends and the local community in the reintegration process;

- Effective access to social protection schemes on the same level as the local population, including addressing the basic needs of vulnerable returnees;

- A 'do no harm' approach to ensure that communities are not negatively affected by the return.

In the meantime, the security situation is worsening and there is still no political solution in sight for a conflict that caused more than half a million people to flee their homes in 2016 - a year which set another record for civilian casualties. ${ }^{50}$ During the first six months of 2017 , there was a $23 \%$ increase in women casualties and a $9 \%$ increase in child deaths. ${ }^{51}$ With frontlines shifting and territorial control disputed, displacement is likely to be protracted - further complicated by time-consuming protection and social cohesion work to support (re)integration of those displaced by the recurring cycles of armed conflict.

Returnees are Afghans. Therefore, unlike refugees hosted by a foreign community and government, they are generally not perceived as outsiders. In fact, they are often not perceived as a specific group, but instead as a family or several families that are living in a certain place. As such, they are hardly ever perceived as threatening to a community. While many Afghans fear conflict, they do not seem to fear returnees as a potential source of conflict.

In many cases, returnees are dependent on social and family networks, which integrate them further into local communities, and may allow them to recover from the shock or disruption of return by themselves. For returnees from Iran, who mostly had mixed reasons for migration (including economic reasons, given Afghanistan's dwindling livelihood opportunities), it is possible to find relatives who can support them. For returnees from Pakistan to Nangarhar, the family support networks equally seem to be a factor of stability and resilience. Often, these networks are involved a few months in advance of the journey to Afghanistan, to arrange housing or a job. The general perception among the interviewees of this research is that, with the exception of deportees, returnees from Iran generally seem to integrate better in Afghanistan, partly because they have often integrated well as individuals into Iranian communities. In contrast, returnees from Pakistan have often lived abroad in groups among
The security situation has deteriorated further. (...)The unrelenting nature of the conflict has affected morale (...). The heavy toll of the fighting on civilians, particularly on women and children, reflects the need for all parties to the conflict to take urgent steps to halt the killing and maiming of civilians $^{49}$

António Guterres, UN Secretary General (June 2017) 
themselves, and more frequently seem to stay in the same groups when returning.

Afghanistan's capacity to absorb returnees is extraordinary, depending to a large extent on the existence of social, tribal and family networks, but it has limits. In Nangarhar, Oxfam's EMMA study shows a capacity for self-recovery and a considerable amount of resilience in the face of shocks and pressures related to the high number of returnees. The reliance on extended family networks is an important finding of this research, as it is at odds with other reports claiming that, because returnees often have been living abroad for decades, they no longer have social networks to fall back on. ${ }^{53}$

While extended family networks are crucial for finding and maintaining labour and housing for returnees, however, reliance on family is in essence a relationship of dependency - it does not remove all vulnerabilities, and might perpetuate some. Even when they can rely on family support, the general perception encountered in this research is that vulnerabilities are higher for unaccompanied minors, single women and female-headed households.

It is also clear that thousands of returnees do not have such a safety net: many families return to landlessness, hardship and abject poverty, when before they had a life with coping mechanisms for arising challenges. With or without family support, many returnees can still not go back to their communities of origin because of insecurity or lack of housing, land or livelihoods.

In general, host communities in the four provinces were found to be neutral or positive about returnees and in many cases acknowledged the need to assist them on their return. But there are two sides to this story. On the one hand, echoing a long tradition of hospitality as an essential aspect of Afghan tribal culture, returnees were often described as 'our brothers' and regarded as a positive contribution to the village, town or city. On the other hand, there are serious concerns about (potential) incidents related to disputes over land and property, which could escalate into violence.

Access to land seems to be a particular concern when connecting the returnee phenomenon with conflict, as noted by a 2016 USIP report: 'Contestation and conflict over land is common and widespread in Afghanistan and significantly affects returnees. Successive waves of internal and external displacement have forced many to vacate land and housing. In some cases, their lands have been occupied by IDPs or other returnees and in other cases by local power brokers. ${ }^{, 55}$ In such cases, it is challenging for returnees to claim their land as they often do not have documentation confirming ownership, or because of the lack of effective formal or informal mechanisms to resolve land disputes. ${ }^{56}$

While they are generally not perceived as a source of conflict, returnees clearly represent competition for jobs or scarce resources and an economic burden on host communities supporting them, as do internally displaced people and economic migrants. Returnees will likely represent a source of future tension and conflict once the burden on host communities and external support mechanisms becomes unsustainable. 
Discrimination against returnees by the host communities was perceived as almost non-existent, although it may arise in some communities where returnees do not have any relationships with the local people or form their own groups. In some cases there is distrust because the local communities do not know exactly who these people are, and may treat them differently - as they would with other outsiders. However, when asked about discrimination by government institutions, concerns were expressed about settlement plans which often relocate returnees to places far removed from urban centres, livelihood opportunities or basic service delivery.

Access to education for the children of returnees is also reported as a problem, which is confirmed by research by Save the Children, UNICEF and the Afghan Ministry of Education. ${ }^{57}$ However, it is not clear to what extent, if at all, this is related to discrimination or to broader challenges such as child labour and early marriage.

An example of distrust and discrimination, often linked to corruption and extortion, is that landlords are reported to charge more rent payments in advance from returnees - six months, instead of the usual three months ${ }^{58}$ citing lack of official identity documents or letters of guarantee. Such demands can limit access to proper housing for some families, and should be considered by any assistance programmes focusing on rent support or housing in general.

Although living in separate groups may hamper the reintegration of returnees, from a logistical point of view it does make it easier to provide humanitarian assistance. This creates its own problems, however: according to some interviewees, such groups often remain aid-dependent as a coping mechanism, perceiving few incentives to become better integrated into the local economy and society even when livelihoods are available. Some returnees, notably in Herat, established their own townships but integrated them into the local economy and urban culture. Others, notably thousands of families from Kunar province who settled in Nangarhar on their return from Pakistan, seem to have established more independent communities.

Many returnees end up settling in cities, assuming that security is better and there will be more livelihood opportunities, especially if they cannot benefit from family networks or connections among host communities. ${ }^{59}$ While there may indeed be more employment opportunities in cities, the returnees also become part of a much broader urbanization process in Afghanistan, which is increasing the competition for jobs. Returnees can find themselves in dire straits if their skills and experience do not match the requirements of the urban labour market. 
Based on the findings of this research, the causes include:

- Lack of integration with host communities: Especially returnees from Pakistan, who often choose to remain in their own groups, with little interaction with host communities. If they originally came from elsewhere in Afghanistan, integration is more difficult and the perception of host communities is less positive. For returnees from Iran, it is reported that their children often face difficulties in integrating in schools because of the different system and curriculum.

- Ethnic, tribal and cultural tensions: Although not perceived as a general trend, there are instances when returnees belonging to one ethnicity or tribe may not be welcomed by another group or even considered to constitute a threat. Sometimes cultural or social differences are involved: if returnees have stayed abroad for a long time, they and their children may behave differently from peers in host communities.

- Urban-rural adaptation challenges: Sometimes the process of rural returnees adapting to cities can lead to friction, although this is reported more for internally displaced people from rural areas, who are generally less educated or accustomed to urban culture.

- Economic pressure and competition for scarce resources: Increasing demand for basic items such as food and water can lead to higher prices and less availability. The increased supply of labour is driving down wages. Many returnees may not find a job, and returnees with skills may have to accept lower-skilled jobs, leading to frustration among the returnees themselves and lower-skilled workers competing with them. Rental prices are going up because of the extra demand from returnees and internally displaced people. Pressure on scarce natural resources may also have a negative impact on the environment: land disputes are particularly a concern, with reports of contentious claims to specific land entitlements and allegations of land grabbing.

- Unequal access to humanitarian assistance for returnees or host communities and corruption linked to support programmes: Some returnees receive support, while others do not, which can lead to grievances or dissatisfaction. The same can occur in host communities if returnee populations receive support while the host community does not benefit from any type of (development) assistance. Corruption can further hamper or distort the equal and effective distribution of aid.

- Psychological pressure: In the interviews and focus group discussions, psychological problems were mentioned several times as a result of returnees being frustrated or disappointed with their conditions. In some cases, this seems to translate into domestic violence.

- Specific vulnerabilities of women and children: Tensions among newly displaced people, returnees and host communities can lead to sexual and gender-based violence (SGBV), such as domestic violence and rape. It can also result in forced (child) marriages and forced labour, with contributory causes including depletion of assets, lack of livelihood opportunities, lack of privacy and general uncertainty. 


\section{HERAT FINDINGS}

Herat is a western province of Afghanistan, bordering Iran. It is both a destination for Afghan economic migrants and a transit route for, often young, Afghans migrating to Europe trying to escape insecurity, conflict or the high levels of unemployment, especially among graduates. While most returnees use Herat as a transit route back to their own provinces, some stay. The province's capital city, also called Herat, is attractive for returnees as it is considered a relatively secure urban area with employment and business opportunities. It a diverse city and people are not tribally connected, so the return and settlement of IDPs does not result in an imbalance of ethnic or other group identities. The city's absorption capacity has so far proved to be high, but there may be limits - especially as returnees who establish new lives for themselves in Herat are often joined by family relations or others from their areas of origin. As Herat is the centre of the western region, it is a magnet for many Afghans looking for more facilities and opportunities.

There are two main border crossings where returnees enter Afghanistan from Iran - Islam Qala in Herat, and Milak in Nimroz province - although at the time of the research, Iran had closed the border at Islam Qala. Between 1,000 and 1,500 people return daily from Iran, and the majority had been using the Islam Qala crossing. Its temporary closure increased returnees' vulnerabilities as Nimroz has fewer facilities to support them. Agencies such as IOM, UNHCR, the Ministry of Refugees and Repatriation, Coordination of Humanity Assistance (CHA) and War Child have offices in Islam Qala to provide financial and legal assistance, as well as protection on arrival. NRC constructed a reception facility to deal with returnees. IOM had been supporting vulnerable undocumented returnees at the border since 2008, with UNHCR assisting documented returnees.

With the help of IOM, the Afghan government has been registering all returnees in an online database - but following the closure of Islam Qala, this system was not operational at the time of research. Upon arrival, some returnees from other provinces are taken to the temporary camp of Ansar, where they can stay for up to 48 hours. The World Food Programme (WFP) distributes food, while IOM provides blankets, clothes and kitchen utensils. IOM also assists host communities, allocating $20 \%$ of its total support to them to help prevent potential tension and conflict.

Nevertheless, some host community members complain that only returnees and internally displaced people receive support. In general, IOM's assistance is more focused on the eastern border with Pakistan, where it has provided post-arrival humanitarian assistance to undocumented returnees since 2012: for example, IOM reports that, for the week of 11-17 June 2017, only $6 \%$ of the undocumented returnees coming from Iran received assistance, while $91 \%$ of returnees from Pakistan were assisted. ${ }^{60}$ By 25 November 2017, this disparity had further increased: $92 \%$ of undocumented returnees from Pakistan assisted, compared with only $5 \%$ from Iran. ${ }^{61}$

This difference is partly explained by the fact that returnees from Pakistan are more likely to form separate communities, while those from Iran are more likely 
to live among host communities, which makes them more difficult to find and support. The independence of returnees from Pakistan mirrors their situation there, often living outside of Pakistani communities. In contrast, Afghan migrants in Iran often seem to live among Iranians in the cities and villages as their neighbours, and have a much closer interaction with their Iranian hosts. That seems to make integration with new Afghan host communities easier after their return. It is important to note, however, that the different integration patterns should not be used by the Afghan government or international support agencies to justify the major discrepancy between support for undocumented returnees from Iran and Pakistan.

The tendency of returnees from Pakistan to have little interaction with the host communities can create tension. A few respondents reported clashes because of misunderstandings between the returnees and the host communities, and a few incidents involving cultural differences, drug addiction or criminal activity. Host communities fear that the number of returnees may increase so much that they will eventually outnumber the host community, affecting their way of life, comfort and stability in the area, and taking control of land. Some cases of land grabbing were already reported.

Eight years ago, the government established Shahrak Saadat, a township for the returnees to live in, and planned to distribute land - but only one of the 13 planned phases of land distribution was completed. Around 300 families received land and built shelters or houses for themselves with the assistance of NGOs, but only 66 of those families have stayed. Many of the houses are now empty, while others are occupied by IDPs from other provinces. Few returnees now choose to live in Shahrak Saadat: although it includes facilities such as a school and a mobile health clinic, and has access to water and electricity, the township is far from Herat City with hardly any transportation. Job opportunities are few, beyond some day labour and seasonal work in surrounding villages, and most efforts to create livelihoods seem to have failed. Some of the returnees in Shahrak Saadat say that the Afghan government and UNHCR encouraged them to leave Iran with the promise of a better future back in Afghanistan, and they now feel deceived.

Interaction with the host communities and surrounding villages is generally perceived as positive - there are examples of returnees and surrounding communities helping one another and the host community benefitting from the establishment of Shahrak Saadat, for example, through NGOs' assistance and the school that was established in the township. The school has become a platform for meetings, social and cultural events, which bring host and returnee populations together.

However, there is a stark difference between Shahrak Saadat and settlements established by the returnees themselves. Although they lack the various forms of assistance provided in government-established townships, people prefer to live in returnee-established townships: integration, livelihood development and ownership are more visible there, with people investing more in their future and creating their livelihoods despite the lack of government or NGO assistance. This suggests that government assistance might be more effective if it targeted townships established by the returnees themselves. 
In Shegofan, another township closer to Herat City, NGOs are providing assistance and basic services to returnees including electricity, water, a health clinic and a school. Returnees and IDPs live in groups, often consisting of original settlers who have later been joined by their relatives. While returnees and internally displaced people live separately from the host community, they are neighbours and share a Community Development Council (CDC), which meets regularly and discusses any arising problems. Having a joint CDC can bring the communities together by offering a platform for communication and dispute resolution.

Some NGOs are also implementing activities that aim to bring the returnees and host communities closer together. Tensions are not reported, but the fear of conflict is there. One example is mentioned which could have become a cause for conflict, had the CDC not facilitated discussions to find a solution: flood water was diverted by the settlement of returnees on higher ground, causing some damage to roads, land and houses. There are some concerns among the host community that the number of returnees will become so high that it will seriously impact employment and basic service levels, while also hampering their integration and adaptation.

Based on the interviews conducted in Herat, it seems most returnees from Iran were economic migrants, many of them individual young Afghans going to Iran for work or travelling onwards to Europe. Many were captured and deported to Herat by the Iranian authorities. Returnees who stay in Herat tend to integrate well - many have bought land and property. However, not all returnees fare so well. Iran has restricted its immigration policies: once you leave Iran as a documented returnee, you are not allowed to travel back, making it very challenging for families who have lived for decades in Iran and have few relatives in Afghanistan to get support prior to their return - the whole family has to come, bringing all their belongings.

In contrast, it is reported that refugees in Pakistan can more easily come to Afghanistan clandestinely and assess the situation to prepare for their family's return. Such 'look and see' visits were generally perceived as a good way increase the chances of successful reintegration. 


\section{KABUL FINDINGS}

Kabul province is located in the central-eastern part of the country, but not directly on the border with Pakistan. After Nangarhar, Kabul province is the second-highest intended return area. ${ }^{62}$ Many returnees end up here because of relatively higher security than in their regions of origin, and the expectation realistic or not - of more job opportunities and support facilities for returnees. By June 2017, Kabul had a total inflow of 680,260 returnees and internally displaced, ${ }^{63}$ including 111,500 undocumented returnees and 203,164 documented returnees from Iran and Pakistan, ${ }^{64}$ and another 10,854 returnees from other countries. ${ }^{65}$ Most returnees live outside of the city centre of Kabul, and often in very remote areas. Many returnees live in camps.

One example of a camp located in urban Kabul is Chaman-e Babrak. Although this is theoretically a better situation than more remote camps, there is hardly any relationship with the host community. The returnees generally come from different cities and have no family ties with the surrounding communities. Similar to the other three provinces, there are no reports of major tensions with the host communities. However, people in the surrounding communities interviewed for this research did express a general sense of fear of the returnees, for example fear of crime, drug addiction and disease. They also perceive the returnees as a source of pressure on the job market and local wages. Some returnees report that, in the beginning, the host communities were suspicious and not welcoming, but this has become better over time.

Integration of returnees with host communities is generally difficult in Kabul province: according to the research, this is partly the cause of the growing establishment of makeshift camps or slums. The creation of such areas is considered to negatively affect the price of land, with few people willing to buy properties or invest in areas with a lot of returnees. Concerns are expressed that host community members may sell their houses and leave the areas where returnees are located. Returnees originating from rural areas face the additional challenge of adapting to new ways of living and often rely in the long term on external support.

In general, there are questions over the capacity of the government and NGOs to deal with the large numbers of returnees in Kabul. Some respondents said that integration will be 'complex and long, if ever it is possible.' Most of the returnees spoken to say that they depend on relatives for accommodation and other in-kind support. Those who have been in Kabul for several years say that the situation was better previously - sometimes, when they first arrived, even better than their situation had been in Iran or Pakistan - but that it has deteriorated, and now they are worse off. Among the perceived changes mentioned by returnees are increased local levels of prices, unemployment, insecurity and crime. Some returnees say that they would never recommend other refugees to return to Afghanistan, and that they again want to leave the country. Some indicated that they have sent their children to Iran or Europe.

To improve integration, the Afghan Women's Educational Center (AWEC) is managing an educational centre for returnee and displaced children in the Taimani area of Kabul. This centre also provides literacy courses and tailoring 
courses for returnee women. A psychologist visits the centre weekly to provide support. Most of the returnees spoken to say their children - boys and girls are going to school. Children interviewed for this research, however, on average say they spend about half of their days as street workers, and that this was not necessary in Pakistan. Some male family members were reported to earn a livelihood as karachiwan (street vendors selling fruits such as figs on their carts). There are very few jobs available, and returnees can generally work only from time to time as daily wage workers. Most returnees cannot find jobs every day, and their earnings are not stable.

In a returnee settlement visited in the Pul-e-Charkhi area, the high number of returns was expected by some people to result in 'fertile ground for the armed groups.' All the refugees in this area have come from Pakistan, and most during the previous year. Some, especially those from Monda camp in Peshawar, were forced to return: the army closed the camp and forced about 1,000 families to leave, many of them ending up in Pul-e-Charkhi because they have relatives there. They are mostly living in small, temporary shelters constructed of mud or other makeshift materials on their relatives' land, uncertain about whether they can stay there permanently. Their main challenges include access to water, sanitation, health and education. It is reported that some of their children tried to go to school, but there were problems of not having the proper documentation. This is sometimes related to reports about bribes being asked by government entities in Pakistan to provide the right signatures or stamps on education certificates. In addition, there is a general perception among returnees that the standard of education and teaching is much lower than in Pakistan.

No major tensions are reported here, which is partly explained in the interviews by the fact that these returnees arrived together in a group and have mostly settled on the lands of their relatives. The close tribal connection was mentioned on several occasions as a factor preventing any disputes from arising. However, there were some reports of fear among host communities that these newcomers might stay for a long time, occupy land and even force the host community out. One guarantee against such fears that was mentioned is that under the shared tribal codes, elders have to commit to leaving the place if requested. This obviously does not improve the security situation of the returnees.

Most documented returnees have received some financial support from UNHCR. Some undocumented returnees received assistance from IOM on arrival. However, they have not received further support from the government or NGOs and this is perceived as very much needed, especially in terms of shelter and basic social services. Interviewees believed that the area will not be able to absorb more returnees or internally displaced people. The general situation is the same for forced and voluntary returnees: few tensions but increased pressure on local resources, jobs, services, and facilities that feeds fears among both returnees and host communities. 


\section{KUNDUZ FINDINGS}

Kunduz province is located in the northern part of the country and shares a border with Tajikistan. By June 2017, Kunduz had a total inflow of 172,963 returnees and internally displaced people ${ }^{66}$ including 19,247 undocumented returnees and 84,200 documented returnees from Iran and Pakistan, ${ }^{67}$ and another 9,101 came from other countries. ${ }^{68}$ With 35,903 additional IDPs in 2017 (as of 3 December), Kunduz province also has the second highest number of internally displaced after Nangarhar. ${ }^{69}$

Kunduz is an extreme case in this research as it is the province most affected by the ongoing conflict, causing high numbers of civilian casualties. The province is also a strategic location for illicit drug trafficking routes towards Central Asia. Armed violence is currently widespread, and the number of internally displaced people is increasing. The province has nine districts, of which four are currently under Taliban control. The city of Kunduz was briefly taken over by the Taliban in September 2015, the first time the insurgent group managed to take over a provincial capital. A year later, in October 2016, the city again came under siege. It had a disastrous impact on people's lives, and many fled to more secure districts, neighbouring provinces or Kabul. Many youth fled towards Europe, mostly through Iran. NGOs were also affected as offices were ransacked and equipment was looted. Escalation of the conflict led to loss of infrastructure, especially in the city centre, Char Dara and Imam Sahib districts. Since then, the city of Kunduz and surrounding areas have come under renewed attacks by the Taliban, causing a lot of uncertainty, instability and insecurity.

This broader context of intense conflict currently overshadows any potential tension between returnees and host communities. But more than in Herat or Nangarhar, there is fear that the arrival of returnees and others will increase competition and upset the ethnic and power reconfigurations in the province. In the focus group meeting organized in Kunduz, it was expressed that such fears and frustrations may provide fertile ground for extremists and criminal groups to recruit and continue to exacerbate the conflict, but no evidence was found during the research to back this up.

The province mainly depends on agriculture and has vast amounts of fertile arable land. However, there is not enough land to provide livelihoods for everyone, due to insecurity, the arrival of returnees and internally displaced people, the natural growth of the population, and recent droughts. High levels of insecurity and conflict prevent the government and NGOs from implementing programmes aimed at improving agriculture, such as introducing new methods of land and water management and distributing seeds and fertilizers. The conflict also limits marketing opportunities for farmers, hampers the creation of new businesses and leads to lack of investment in the economy. Most returnees have come from Pakistan and many are semi-skilled labourers, such as electricians and masons, but there are few job opportunities. Cross-border trade with Central Asian republics has been reduced significantly: for example, most of the shops at Sher Khan Bander, a town on the border with Tajikistan, are now abandoned. 
Most of the returnees in Kunduz originally also came from the province - due to the conflict, not many returnees from other provinces are coming to Kunduz. Returnees going back to their own communities of origin often end up settling down in Taliban-controlled or insecure areas. The conflict provides additional challenges as returnees are often unaware of the complex situation of shifting frontlines and military operations. Some returnees have suffered a double tragedy: after returning from abroad, they have become internally displaced because of the conflict. As in Herat, the government had planned to construct a township for returnees but the land had not yet been distributed at the time of research. A few cases of land grabbing or occupation were reported, but in general there seem to have been very few disputes.

The Afghanistan Independent Human Rights Commission (AlHRC) is providing consultation and legal assistance to returnees and IDPs. It also monitors the human rights situation, producing two reports a year. When interviewed for this research, AIHRC confirmed that there have been few cases of conflict between returnees and host communities, though there have been some reports of harassment and violence against women involving returnees. UNHCR is supporting documented returnees. Further support comes from international NGOs such as ACTED, NRC and Oxfam, through its local partner ADA. Challenges reported are lack of shelter, water, sanitation and hygiene, and access to education for their children. NRC is running a school and providing emergency shelter, as well as legal assistance. Some people in Taliban-controlled areas complain about the lack of assistance coming their way, when compared with government controlled areas: the conflict means support is mostly limited to short-term emergency response projects in areas controlled by the government.

ADA is assisting returnees in Char Dara district, which is under the control of the Taliban. An August 2016 assessment by Oxfam and ADA found that support for agriculture and rural livelihoods is urgently needed to prevent chronic food insecurity. The two organizations have jointly supported returnees and conflict-affected families with emergency food aid, cash-for-work projects to rehabilitate roads, canals and dams, and the distribution of agricultural inputs and tools. As in Nangarhar, Oxfam and ADA have been running an emergency food aid and winterization programme for returnees, host communities and IDPs, using mobile cash transfer technology. Oxfam has also been working with AHEAD to provide livelihood support (in the form of poultry, fertilizer and tailoring), cash assistance and cash-for-work to some of the most vulnerable returnee families and host communities to increase food security.

Many young Afghans from Kunduz have left for Europe: around 140 were reported to have left Char Dara in 2016, and so far only four have come back. One, deported from Germany, reported having received $\$ 300$ (roughly $€ 260$ ), and another one $\$ 700$ (roughly $€ 615$ ). In comparison, the average daily wage is around 200-250 afghanis (around \$2.9-3.6 or €2.5-3.1). Those who returned voluntarily were reported as not having received assistance.

In Imam Sahib district, returnees are mostly semi-skilled labourers from Pakistan, some living with their relatives and some with their own land and house. The security situation is better than in Char Dara, although there are dispersed clashes between the Taliban and the government. The increase in population has put pressure on livelihoods: unemployment is high and few job 
opportunities are available, although there is some work in agriculture as the land is generally fertile.

In Ali Abad district, some individuals have returned from Iran and are living with their families, but many have been displaced: at the time of the research, control over the district was divided between the government and the Taliban, almost along ethnic lines, which has caused many families to flee from insurgent-controlled areas. Some families have gone to Kabul, some are living in dire circumstances with relatives in Kunduz, and some are constantly on the move. Host communities are generally accepting and helpful, though it was also reported that tensions may rise if the numbers increase further and the conflict continues. Some returnees or IDPs can find day labour for about 200 to 300 afghanis (roughly $\$ 2.9-4.4$ or $€ 2.6-3.8$ ), but this is not enough for a sustainable livelihood. There are very few shelters and hardly any emergency response.

The conflict in Kunduz has many causes, and impacts the lives of local people in various ways. The huge numbers of returnees coming back to such a fragile environment puts additional strains on scarce resources, increasing vulnerabilities and fears about changes to social and ethnic balances. In such a situation, the high number of returnees can easily reinforce the vicious cycle of conflict, vulnerability and poverty. 


\section{NANGARHAR FINDINGS}

Nangarhar is an eastern province, bordering Pakistan. By June 2017, it had a total inflow of 780,375 returnees and internally displaced people,${ }^{70}$ including 231,823 undocumented returnees and 287,042 documented returnees from Iran and Pakistan, ${ }^{71}$ and 5,948 returnees from other countries. ${ }^{72}$ With 75,980 additional IDPs in 2017 (as of 3 December), Nangarhar also has the highest number of internally displaced people. ${ }^{73}$

Most returnees in Nangarhar are from Pakistan, with relatively few from Iran and hardly any from Europe. It is common for returnees to have been in Pakistan for 20 years or more. Many had been residing in Khyber Pakhtunkhwa, one of the four administrative provinces of Pakistan, until a mixture of domestic and regional political issues in 2016 led to increased harassment and pressure to return to Afghanistan. More than 300,000 of those forced into movement are now estimated to be in Nangarhar, which connects with Pakistan through the Torkham crossing.

People from insecure districts have fled to safer districts such as Behsud and Surkh Rod. In Surkh Rod, there is a camp for returnees and IDPs. Others live with family, in makeshift dwellings or in rented houses. As in the other three provinces, the general perception is that the situation of IDPs seems to be much worse than that of returnees, who can generally bring their belongings, receive support from relatives, and have some time to plan and prepare their trip. In contrast to the findings in Herat, some returnees from Nangarhar mention that they were able to prepare well for their trip before returning from abroad. They had visited Afghanistan a few times prior to their return, bought land, established houses and then decided to bring their families from Pakistan.

Those returnees with documents used to receive about $\$ 400$ (roughly $€ 340$ ) per family member from UNHCR, which was reduced in April 2017 to $\$ 200$, and some can buy a house or land to settle down. Returnees who do not stay in Nangarhar usually travel onwards to Kabul, Baghlan or Kunduz.

There are relatively few reports about increased tensions, insecurity or conflict because of the arrival of returnees. Local people are generally helping them out, although there are some reports that communities are starting to become less tolerant as numbers increase. Most returnees live with their relatives and share their food and accommodation, which improves their conditions, but of course places a heavy burden on these families, especially as it is unclear how long this support will be necessary.

The returnees typically have vocational skills which are welcomed by host communities. In some cases, they also bring the tools of their trade with them, such as rickshaws - though the resulting oversupply of rickshaws has reportedly led to pollution and traffic jams. As in the other three provinces, one of the main challenges seems to be access to education for children and to healthcare: these basic services are in limited supply and have difficulty coping with so many returnees and IDPs. 
Some incidents of disputes are reported, especially related to land grabbing when big groups of returnees, originally from other areas, settle down and invite their relatives to join them. For example, hundreds of returnees who were originally from Kunar province have settled in one big area in Behsud district. In another example, returnees from Khogyani district settled in an area of Behsud, after which people with links to the Taliban were seen in that area and rumours of extremist ideology were heard. It was reported that a few, especially female, returnees had an extremist mind-set due to their education in Pakistani madrassas, and they promoted such ideologies among the host communities. Fearing that extremist groups may get a foothold, the local community decided to push these returnees out of their area, which resulted in some tension. There is, however, no evidence of widespread links between returnees and insurgent groups or extremist views.

Other cases of conflict represent a resurgence of hostilities which existed before the refugees fled to Pakistan, and erupted again when they came back from exile. Still others relate to psychological problems among returnees who cannot find jobs or have difficulties adapting to their new situation. Women and children are reported as suffering the most: interviewed for this research, AlHRC reports an increase in the number of domestic and women-related violence cases involving returnee families. Some friction is also caused by cultural differences, with returnees' children sometimes considered to be rude - but most such disputes are small-scale and resolved at the local level by elders or other authorities.

UNHCR provides cash to documented returnees. Many humanitarian aid organizations provide emergency assistance in Nangarhar, but there is a perception that coordination is often lacking, with hardly any effective mechanisms to avoid duplication and to increase outreach. Those who do not have documents receive some food and non-food items from international organizations such as IOM, UN OCHA, the United Nations Population Fund (UNFPA) and international NGOs such as Action Aid, AHEAD, NRC and Oxfam's local implementing partners, which focus on WASH, cash transfers, food aid and shelter. NRC is providing food and non-food assistance for refugees and returnees, mainly through short-term emergency response projects.

Oxfam has been working with AHEAD on a support programme which has facilitated cash transfers of between $\$ 90$ and $\$ 150$ (roughly $€ 79$ and $€ 132$ ) to undocumented returnee families to meet their immediate food security and winterization needs. Implemented in Surkh Rod, Jalalabad City, Kama and Behsud districts, this programme is also providing livelihood support to host communities.

With the help of IOM, the Provincial Department of Refugees and Repatriation has implemented an online database system to register returnees. Supported by international donors, they also provide some cash to undocumented returnees, around 3,500 afghanis per family (around $\$ 51$ or $€ 45$ ).

The rapid increase in supply of labour is putting severe pressure on the labour market in Nangarhar, as demand for labour is increasing more modestly; new jobs are mostly in construction and the sale of basic commodities. The Emergency Market Mapping and Analysis $\left(\mathrm{EMMA}^{74}\right)$ study conducted by 
Oxfam in March and April 2017 found that the average daily wage has fallen since March 2016 by an average of $12 \%$ for unskilled and $20 \%$ for skilled forms of labour across five key industries: agriculture, construction, loading and transport, small-scale services and skilled trades. Job seeking has become more challenging and competitive. The EMMA study suggests that the average labour-reliant household found an average of 13 days of work in March 2017, in comparison with 18 days in March 2016. This suggests a decrease of average wages of 2,000 afghanis (roughly \$29.5 or €27) per month. This is having an impact on the household budgets of all who rely on income from labour.

In Nangarhar, access to the labour market is highly mediated by family and social networks, though community leaders, private contractors and public labour also play a role. At the time of the research, there was little evidence of discrimination against returnees or internally displaced persons; when this had been observed, it generally focused on lack of trust related to security concerns - for example, if IDPs originate from insecure areas. Returnees are generally perceived to possess more skills than the host community but are also seen as lacking 'familiarity' with Nangarhar, in the sense of connections to facilitate finding labour.

Like the labour market, the housing market in Nangarhar is highly mediated by family and social networks, though community leaders and private housing agents play a role. The large increase in demand for housing has not yet been matched by a sufficient increase in housing stock. A number of longer term policy and strategic issues compound challenges in expanding the housing market, including land use and urban growth policies, local-level governance challenges and insecurity. The province, and especially urban and peri-urban Jalalabad, was already under significant growth and expansion pressures before the returnees arrived. The EMMA study found that the average rental price for a modest house suitable for a family of seven had increased in one year from 4,100 afghanis ( $\$ 60.5$ or $€ 55.5$ ) per month to 5,250 afghanis ( $\$ 77.5$ or $€ 71$ ), a gap of 1,150 afghanis ( $\$ 17$ or $€ 15.5$ ) per month.

The majority of returnees, both documented and undocumented, report an intention to remain in Nangarhar. That means more urban growth and further strains on resources, local prices, livelihoods and infrastructure. The city's infrastructure is already very old, and was designed for far fewer people: the huge numbers of returnees and IDPs are leading to overcrowding, traffic jams, and the growth of slum-like neighbourhoods. It is the type of environment in which the tolerance of host communities will be put to the test and tension and conflict can quickly increase. 


\section{CONCLUSION AND FUTURE SCENARIOS}

\section{CONCLUSIONS}

The starting point in assessing whether the arrival of returnees increases tensions and poses concerns for their safety should be the bigger picture of the highly fragile and conflict-affected environment in Afghanistan. Figure 3 shows how this environment could be affected by some of the key factors and pressure points found during this research.

Figure 3: Potential pressure points affecting Afghanistan from returnees and host communities

\section{FRAGILE AND CONFLICT AFFECTED SITUATION OF AFGHANISTAN}

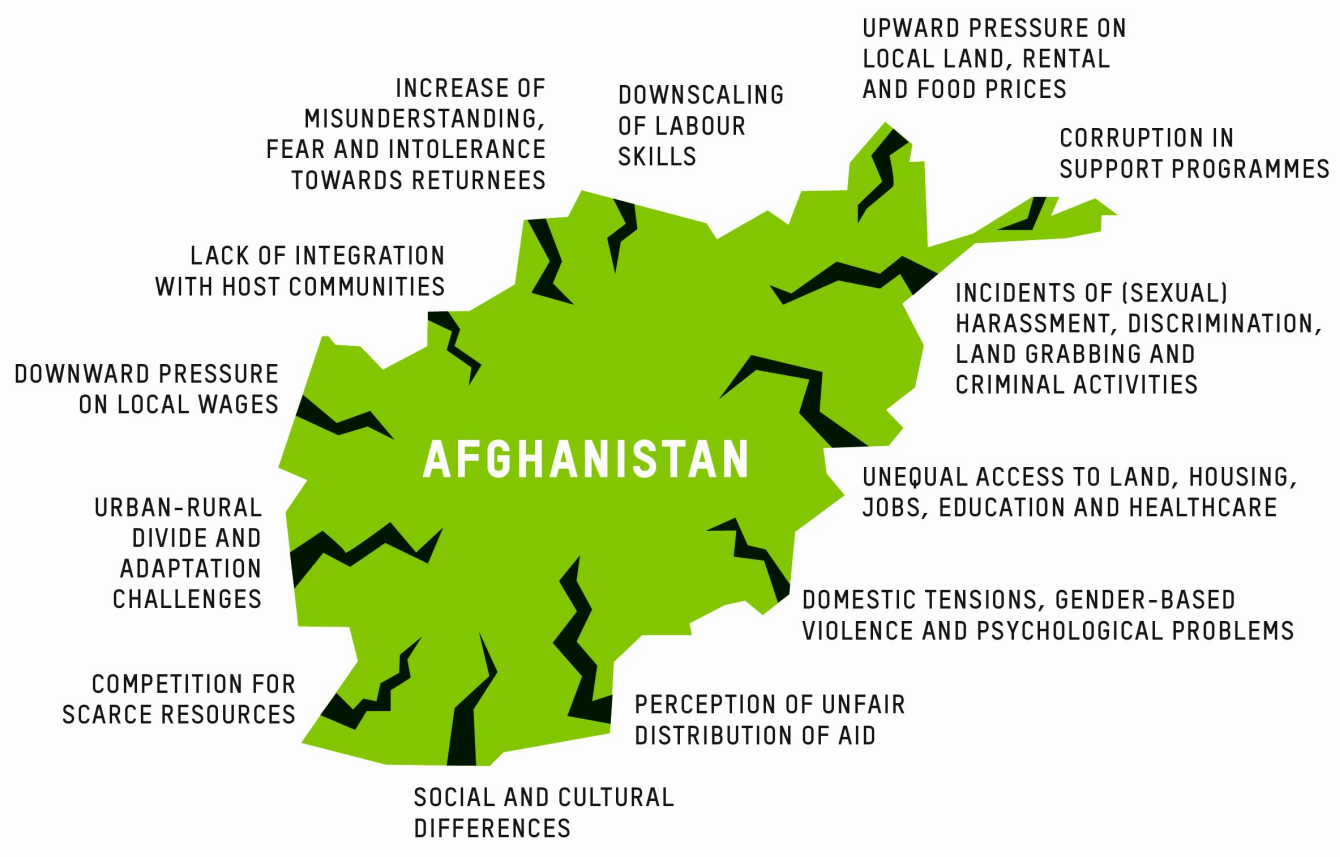

It is clear that returnees are returning to a highly fragile situation, especially in Kunduz and Nangarhar. While there is currently little evidence that it is fuelling structural instability, insecurity or conflict, it is evident that the returnees are putting pressure on scarce resources and many are concerned that Afghanistan has reached the limit of its absorption capacity. Additional pressure is building up where other sources of friction are already creating and increasing vulnerabilities. 
Afghanistan is currently a 'pressure cooker' of ongoing conflict, inadequate infrastructure, scarce resources, the arrival of IDPs, a malfunctioning government, entrenched corruption, extremist ideologies and the presence of criminal groups. A proper debate on the situation of returnees in Afghanistan, and on the decision to send Afghans back, cannot take place without taking into account this broader context of fragility.

There is a self-help system in place which currently seems able to resist some of the pressure building up, but with clear limitations, as many families returning to Afghanistan cannot benefit from it. Host communities and extended social and family networks tend to assist returnees where they can. They are generally welcoming towards returnees, although this positive attitude may change over time, as suggested by incidents involving accusations of land grabbing and other disputes. The challenges are being created not by the returnees themselves, but by the fact that they return in such high numbers, in such a short time span, and to such a fragile situation.

Indirectly, returnees may contribute to the fragility of the government, as the support infrastructure and programmes increasingly fail to deal effectively with their arrival. This means both returnees and host communities will increasingly doubt the capacity and perhaps even the legitimacy of the government. But even such an indirect causal effect must be seen within a broader framework where many different actors and factors are currently sustaining or increasing insecurity and instability.

At the moment, there seems to be no clear causality between the arrival of returnees and recruitment or support for insurgent groups. In some areas, there may be some correlation, but always within the broader picture of fragility and conflict, in which it is difficult or impossible to single out returnees as key drivers of conflict. For example, although some returnees may choose or be forced to join an insurgent group - a possibility hardly reported during the field research - the same goes for host community members or other Afghans. Poor living conditions undoubtedly play a role in such cases, which is why the concern is expressed that insurgent groups could try to exploit the dire situation in which many returnees and IDPs find themselves, or some of the disputes and friction that they may become involved in. There are anecdotal reports of coerced recruitment, but not only by insurgent groups - also by the Afghan security forces. Another concern is that some returnees may bring extremist views back to Afghanistan, but there is no evidence that this happens on a substantial scale.

The case of Nangarhar province shows a significant impact of the returnee (and IDP) populations on the labour and housing markets. Average monthly incomes have decreased significantly, while rental prices have gone up. However, there is little evidence that this market pressure is yet translating into increased tension and conflict.

When returnees live in separate groups, without proper integration within the host communities, there tends to be more potential for tension to arise. With less interaction, the possibilities for misunderstandings, friction, fear and discrimination to arise are higher. However, ethnic diversity is not necessarily a cause for more friction and disputes. 
The combination of international support and local social and family support networks is currently still able to provide some absorption capacity to deal with the high number of returnees. However, with the additional challenge of huge numbers of internally displaced people fleeing conflict, there is a clear limit to Afghanistan's coping mechanism.

Overall, returnees seem to be better off than the internally displaced. That is another reason for looking at the bigger picture of conflict and fragility in Afghanistan, instead of focusing only on returnees - but the situation of both groups urgently needs more attention.

\section{FUTURE SCENARIOS}

\section{The 'Absorption Stretch' scenario (likelihood: low)}

This scenario represents the status quo. Although hundreds of thousands more returnees come back from Iran, Pakistan and, to a much lesser extent, from Europe, the combination of international support and the self-regulatory social and family networks can stretch enough to allow Afghanistan to cope. However, this proves to be possible only with additional support and a greater sharing of responsibility by the international community. From 2018 onwards, deportations from Iran and Pakistan start to decrease, which helps to absorb the new returnees. The number of incidents related to increased discrimination, friction, tensions and disputes between returnees and host communities remains limited and relatively easy to resolve locally.

\section{The 'Rising Inequality' scenario (likelihood: high)}

This scenario departs from the status quo through increased inequalities, vulnerabilities and tension. Social and family networks, the broader hospitality of host communities and international support programmes all start to reveal their limits. More and more returnees lack access to a proper reception, support base and opportunity to effectively (re)integrate in host communities. The contrast becomes bigger between returnees who can benefit from local support and those who become marginalized within or outside local communities. As a result, more and more returnee groups and individual returnees live in dire circumstances and no longer benefit from international support. There is an increase in tension in some communities, but this remains limited, partly because of the growing distance between certain returnee populations and local communities.

\section{The 'Heightened Tensions' scenario (likelihood: high)}

This scenario is the next step on the tension-escalation ladder. The economic downturn, high unemployment rate and lack of sufficient support to host communities increasingly limit their levels of acceptance and tolerance. There is unsustainable pressure on basic social services and the support infrastructure. Slums are established in many areas, where returnees live in dire conditions. Host communities increasingly start to see returnees as outsiders and their direct competitors for livelihoods and other scarce resources. As a consequence, there is a notable increase in local friction and tension, even involving some armed clashes and other violent incidents. 
Around the country, there are reports of incidents that leave people wounded and even dead. The government and international community are not willing to intervene with funding, programming and technical support to decrease rising tensions, and insurgent groups try to exploit the situation as much as they can to pit people against the government or each other.

\section{The 'Perfect Storm' scenario (likelihood: low):}

In this worst-case scenario, the continuing return leads to humanitarian tragedy. ${ }^{75}$ Even with the support of the international community, support mechanisms collapse under the continuous arrival of hundreds of thousands of returnees throughout 2018 and 2019. Efforts to properly assist people are cancelled out by the large numbers of returnees arriving each day. An increase in fighting across Afghanistan further increases the number of internally displaced, which creates additional pressure. More and more makeshift returnee camps spring up at the border crossings with Iran and Pakistan, as well as in urban centres. More criminal activities involving returnees are reported, as poverty leaves them no other option - but reports about this are blown out of proportion by local media, and feed fear and distrust. There are more cases of discrimination and even violence against returnees. While there are some protests in Kabul and other provinces demanding more attention to what has now become a severe returnee crisis, the government lacks the capacity to deal with this challenge and the international community is not willing to provide more support. From 2018 onwards, the United Nations reports increased humanitarian and development needs of returnee populations that largely go unmet. 
1 UNAMA. (2017). Afghanistan Protection of Civilians in Armed Conflict Quarterly Report. Retrieved 8 December 2017, from

https://unama.unmissions.org/sites/default/files/unama protection of civilians in armed_confli ct_quarterly_report_1_january_to_30_september_2017__-_english.pdf

2 For 2016, the UN Afghanistan Mission for Afghanistan (UNAMA) reported 11,418 civilian casualties $(3,498$ deaths and 7,920 injured), representing a $2 \%$ decrease in deaths and $6 \%$ increase in injured compared with the previous year. Over the first nine month of 2017, UNAMA reports a $6 \%$ decrease of civilian casualties compared with the same period in 2016. NATO has extended the Resolute Support mission, which focuses on training and assisting the Afghan National Security Forces. NATO expects that the number of international forces will again increase with 3,000 to about 16,000 , a clear sign that insecurity and instability is on the rise. In September 2015, the Taliban temporarily controlled the city of Kunduz and attacked it again in October 2016. In September 2016, the city of Tarin Kowt in Uruzgan province was on the verge of being taken over by the Taliban. At the time of writing, heavy fighting was taking place in Kunduz and neighbouring province Baghlan, areas in the north of Afghanistan that were considered relatively secure throughout most of the International Security Assistance Force (ISAF) period. Lastly, Islamic State is consolidating its presence in the eastern parts of country with increased activities reported as well in northern provinces of Jowzjan and Sari Pul, as well as in the western provinces of Herat and Ghor, For an update on civilian casualties, see: UNAMA. (2017). Afghanistan Protection of Civilians in Armed Conflict Quarterly Report. Retrieved 8 December 2017, from https://unama.unmissions.org/sites/default/files/unama protection of civilians in armed confli ct_quarterly_report_1_january_to_30_september_2017_-_english.podf

3 UN OCHA. (2017). Humanitarian Response Plan. Mid-Year Review, January-June 2017 Retrieved 8 December 2017, from

https://www.humanitarianresponse.info/en/operations/afghanistan/document/afghanistan-2017humanitarian-response-plan-mid-year-review-january

4 The data is taken from the Asylum Quarterly Reports of Eurostat for this period. Retrieved 8 December, from http://ec.europa.eu/eurostat/web/asylum-and-managed-migration/publications

5 Interview: Mark Bowden on his time in Afghanistan and on revamping international aid', (2017). UN News Centre, 31 March. Retrieved 6 December 2017, from http://www.un.org/apps/news/story.asp?NewsID=56476

6 R Marx. (2002). The Criteria of Applying the "Internal Flight Alternative" Test in National Refugee Status Determination Procedures. International Journal of Refugee Law, 14 (2/3).

7 Taken from the Financial Tracking Service's data on the Afghanistan Flash Appeal: One Million People on the Move (September-December 2016). Retrieved 8 December, from https://fts.unocha.org/appeals/525/flows

8 For the Returnee Resilience Measure Index (RRMI), see: NRC and Samuel Hall. (2016). From Returns to Building Resilience: A Tool for NRC to measure change. For the Emergency Market Mapping and Analysis (EMMA) Toolkit, see its website: http://www.emma-toolkit.org/

9 UNHCR. (1996). Handbook Voluntary Repatriation: International Protection. Geneva: UNHCR, 11.

10 Organizations such as the United Nations Refugee Agency (UNHCR), the United Nations Office for the Coordination of Humanitarian Affairs (UN OCHA) the International Organization for Migration (IOM), the Danish Refugee Council (DRC), the Danish Demining Group (DDG), the United States Institute of Peace (USIP), the Norwegian Refugee Council (NRC), Oxfam, the Afghan Analysts Network (AAN), Human Rights Watch and Samuel Hall, have been involved in research and reporting on the situation of returnees.

11 Oxfam. (2017). Labour and Housing Market Systems in Nangarhar Province, Eastern Afghanistan (Complex Conflict, Displacement, and Returnee Influx), Emergency Market Mapping and Analysis. Retrieved 8 December 2017, from http://fscluster.org/sites/default/files/documents/nangarhar_emma_report_final_12th_may_2017.pdf

12 Director of National Intelligence Dan Coats speaking during a US Senate Intelligence Committee hearing on Global Threats. 11 May 2017.

13 Together with several other civil society organizations, Oxfam has expressed serious concern about the Joint Way Forward deal, not only because of the secretive way in which the deal was reached, but also because of the risk that development aid becomes conditional on the collaboration of the Afghan government to accept Afghans who are being sent back. In a joint open letter to the European Parliament of 24 October 2016, Oxfam and 26 other NGOs have expressed these concerns. Retrieved 8 December 2017, from https://reliefweb.int/sites/reliefweb.int/files/resources/joint_statement_eu-afghanistan_deal.pdf

14 The table is based on various sources: Eurostat; International Organization for Migration (IOM); UN Office for the Coordination of Humanitarian Affairs (UN OCHA); United States Institute of 
Peace (USIP); Afghanistan Analysts Network (AAN).

15 Undocumented returnees are understood here as those who were not registered as refugees in Iran, which means they do not have the official refugee status and the protection it entails under international law.

16 'Iran Continues Deporting Undocumented Afghan Refugees', (2017). Voice of America, 21 May. Retrieved 8 December 2017, from https://www.voanews.com/a/iran-continues-deportingundocumented-afghan-refugees/3864010.html

17 'Pakistan Reveals Plan to Repatriate Afghan Refugees', (2015). Voice of America, 2 November. Retrieved 8 December 2017, from https://www.voanews.com/a/pakistan-afghanrefugees-repatriation-plans/3032948.html

18 Data extracted on 28 September 2017 from Eurostat's Asylum Quarterly Report. Retrieved 8 December 2017, from http://ec.europa.eu/eurostat/statisticsexplained/index.php/Asylum_quarterly_report\#Main_trends_in_the_numbers_of_asylum_appli cants

19 'Germany Suspends Afghan Deportations after Kabul Blast', (2017). Al Jazeera, 1 June. Retrieved 8 December 2017, from http://www.aljazeera.com/news/2017/06/germanysuspends-afghan-deportations-kabul-blast-170601165442219.html

20 The Criteria of Applying the "Internal Flight Alternative" Test in National Refugee Status Determination Procedures, op. cit.; H. Lambert. (2006). The RU Asylum Qualification Directive, Its Impact on the Jurisprudence of the United Kingdom and International Law. International \& Comparative Law Quarterly, 55(1), 161-192.

21 The Council of the European Union. (2004). Council Directive 2004/83/EC of 29 April 2004 on minimum standards for the qualification and status of third country nationals or stateless persons as refugees or as persons who otherwise need international protection and the content of the protection granted, Article 8(1). Retrieved 8 December 2017, from http://eurlex.europa.eu/legal-content/EN/TXT/PDF/?uri=CELEX:32004L0083\&from=EN

22 Registered returnees coming from Pakistan receive $\$ 200$ from the UN Refugee Agency (UNHCR). Although this was temporarily increased to $\$ 400$ in June 2016, this decision was reversed again in April 2017. Voluntary returnees from Europe may receive an estimated amount between $€ 500$ and $€ 1,200$, depending on which country they return from. In all cases, this financial support is a one-off contribution for immediate needs or reintegration.

23 UNDP. (2016). Human Development Report 2016: Human Development for Everyone. New York: UNDP

24 lbid., 218.

25 UN OCHA. (2017). 2017 Humanitarian Response Plan. Retrieved 8 December 2017, from https://docs.unocha.org/sites/dms/Afghanistan/afg_2017_hrp_english.pdf. The Mid-Year Review of this plan can be retrieved from

https://www.humanitarianresponse.info/en/operations/afghanistan/document/afghanistan-2017humanitarian-response-plan-mid-year-review-january

26 UNHCR. (2017). Highlighted Underfunded Situations in 2017. Geneva: UNHCR, 12. Retrieved 8 December 2017, from

http://reporting.unhcr.org/sites/default/files/UNHCR\%20Brochure\%20on\%20Underfunded\%20 Situations\%20in\%202017\%20-\%200ctober\%202017.pdf

27 UN OCHA. (2016). 2017 Humanitarian Response Plan, op. cit., 9.

28 Human Rights Watch. (2017). Pakistan Coercion, UN Complicity: The Mass Forced Return of Afghan Refugees, 71. Retrieved 8 December 2017, from http://www.acbar.org/upload/1487131822499.pdf

29 UNHCR and the World Bank. (2016). Fragility and Population Movement in Afghanistan, 10. Retrieved 8 December 2017, from http://documents.worldbank.org/curated/en/315481475557449283/Fragility-and-populationmovement-in-Afghanistan

30 UNHCR. (2015). Enhanced Voluntary Return and Reintegration Package for Afghan Refugees (EVRRP), 4. Retrieved 8 December 2017, from http://www.unhcr.org/562defe26.pdf

31 M. Huber and M. Zupancic. (2014). Danish Demining Group (DDG) Afghanistan Community Safety Survey, 27. Retrieved 8 December 2017, from

https://reliefweb.int/report/afghanistan/ddg-afghanistan-community-safety-survey

32 Ibid., 26.

33 United Nations. (2017). Special report on the strategic review of the United Nations Assistance Mission in Afghanistan. Report of the Secretary-General. Retrieved 8 December 2017, from https://unama.unmissions.org/sites/default/files/special_report_on_the_strategic_review_of_the _united_nations_assistance_mission_in_afghanistan.pdf

34 Transparency International and Integrity Watch Afghanistan. (2016). National Integrity System Assessment Afghanistan 2015. Retrieved 8 December 2017, from https://www.transparency.org/whatwedo/publication/afghanistan_2015_national_integrity_syste m_assessment

35 A. Thier and S. Worden. (2017). Political Stability in Afghanistan: A 2020 Vision and Roadmap. United States Institute of Peace Special Report. Washington: USIP. Retrieved 8 December 
2017, from http://reliefweb.int/sites/reliefweb.int/files/resources/sr408-political-stability-inafghanistan-a-2020-vision-and-roadmap.pdf

36 Taken from the website of the International Displacement Monitoring Centre (IDMC): Afghanistan: Mid year update 2017 (January-June). Retrieved 8 December 2017, from http://www.internal-displacement.org/countries/afghanistan

37 lbid.

38 UN OCHA. (2017). Afghanistan Weekly Field Report. Week of 27 November - 3 December 2017. Retrieved 8 December 2017, from https://www.humanitarianresponse.info/system/files/documents/files/20171204_afghanistan_w eekly_field_report_27_november_-_03_december_2017_en.pdf

39 'Civilians Continue to Bear the Brunt of Afghanistan's "Ugly War" - UN report', (2017). UN News Centre, 17 July. Retrieved 8 December 2017, from http://www.un.org/apps/news/story.asp?NewsID=57189

40 Amnesty. (2017). Afghanistan: Civilian Casualties Show How Unsafe It Is for Refugees to Be Returned. Retrieved 8 December 2017, from https://www.amnesty.org/en/latest/news/2017/04/afghanistan-civilian-casualties-show-howunsafe-it-is-for-refugees-to-be-returned; Pro Asyl. (2017). Afghanistan: No Safe Country for Refugees: An Investigation into the Country's Political and Economic Situation, its Internal Security and the Situation of Refugees. Frankfurt: Pro Asyl. Retrieved 8 December 2017, from https://www.proasyl.de/wp-

content/uploads/2017/05/PRO_ASYL_Afghanistan_Broschuere_englisch_web_Mai17.pdf

41 Amnesty International. (2017). Forced Back to Danger: Asylum-Seekers Returned From Europe To Afghanistan. London: Amnesty International. Retrieved 8 December 2017, from https://www.amnesty.org/es/documents/asa11/6866/2017/en/

42 'Germany Suspends Afghan Deportations after Kabul Blast', op. cit.

43 J. Bjelica and F. Muzhary. (2016). Afghan Exodus: Can the Afghan government deal with more returnees from Europe? Article in a series on migration of the Afghan Analysts Network (AAN) and the Friedrich Ebert Stiftung (FES). Retrieved 8 December 2017, from https://www.afghanistan-analysts.org/afghan-exodus-can-the-afghan-government-deal-withmore-returnees-from-europel

44 UN OCHA. (2017). Pakistan: Afghan Refugees and Undocumented Afghans Repatriation (1925 November 2017). Factsheet. Retrieved 8 December 2017, from https://reliefweb.int/sites/reliefweb.int/files/resources/afghan_returns_20171125.pdf

45 Undocumented returnees are understood here as those that were not registered as refugees in Iran, Pakistan or other countries, which means they do not have the official refugee status and protection it entails under international law.

46 Pakistan: Afghan Refugees and Undocumented Afghans Repatriation (19 - 25 November 2017), op. cit.

47 ACAPS. (2017). Undocumented Returnees from Pakistan and Iran. briefing note, 2. Retrieved 8 December 2017, from https://www.acaps.org/country/afghanistan/special-reports

48 A. Fonseca, L. Hart and S. Klink. (2015). Reintegration: Effective approaches. Geneva: IOM, 20. Retrieved 8 December 2017, from https://www.iom.int/sites/default/files/our_work/DMM/AVRR/Reintegration-Position-Paperfinal.pdf

49 United Nations. (2017). The Situation in Afghanistan and Its Implications for International Peace and Security. Report of the Secretary-General. Retrieved 8 December 2017, from https://unama.unmissions.org/sites/default/files/sg_report_on_afghanistan_-_15_june_2017.pdf

50 Humanitarian Response Plan. Mid-Year Review, January-June 2017, op. cit.

51 lbid.

52 UN OCHA. (2017). Mark Bowden Farewells Afghanistan. Afghanistan Humanitarian Bulletin, 61. Retrieved 8 December 2017, from https://reliefweb.int/sites/reliefweb.int/files/resources/afghanistan_monthly_humanitarian_bulleti n_february_2017_1.pdf

53 See for example: 'Afghanistan's Security Situation "Has Deteriorated"', (2017). Deutsche Welle. 31 May. Retrieved 8 December 2017, from http://www.dw.com/en/afghanistans-securitysituation-has-deteriorated/a-39061123

54 President Ghani Chairs Meeting on Refugees and Returnees', (2017). Office of the President, 9 October. Retrieved 8 December 2017, from https://president.gov.af/en/news/president-ghanichairs-meeting-on-refugees-and-returnees/

55 B. Ahmadi and S. Lakhani. (2016). The Forced Return of Afghan Refugees and Implications for Stability. Peacebrief, 199. Washington: USIP, 3. Retrieved 8 December 2017, from https://www.usip.org/sites/default/files/PB199-The-Forced-Return-of-Afghan-Refugees-andImplications-for-Stability.pdf

56 J. Bjelica. (2016). Afghanistan's Returning Refugees: Why Are So Many Still Landless?. Afghan Analysts Network (AAN). Retrieved 8 December 2017, from https://www.afghanistananalysts.org/afghanistans-returning-refugees-why-are-so-many-still-landless/

57 Save the Children, UNICEF and the Ministry of Education. (2016). Rapid Assessment of 
Education Needs of Returnee Children in Afghanistan. Retrieved 8 December 2017, from https://www.humanitarianresponse.info/en/operations/afghanistan/assessment/rapidassessment-education-needs-returnee-children-afghanistan

58 Labour and Housing Market Systems in Nangarhar Province, Eastern Afghanistan, op. cit., 11.

59 Undocumented Returnees from Pakistan and Iran, op. cit., 2.

60 IOM. (2017). Return Of Undocumented Afghans, Weekly Situation Report, 11-17 June 2017. Retrieved 8 December 2017, from

https://www.iom.int/sites/default/files/situation reports/file/IOM Afghanistan Return of Undoc umented_Afghans_Weekly_Situation_Report_11_17_June.pd $\bar{f}$

61 IOM. (2017). Return Of Undocumented Afghans, Weekly Situation Report, 19-25 November 2017. Retrieved 8 December 2017, from

https://afghanistan.iom.int/sites/default/files/Reports/final_iom_afghanistan-

_return_of_undocumented_afghans-_situation_report-_19-25_november_2017.pdf

62 ADEO. (2016). Brief Assessment Report of Kabul Returnees. Retrieved 8 December 2017, from https://www.humanitarianresponse.info/en/operations/afghanistan/assessment/briefassessment-report-returnees-kabul

63 IOM. (2017). Displacement Tracking Matrix (DTM), Afghanistan Baseline Mobility Assessment, Summary results. Kabul: IOM, 3. Retrieved 8 December 2017, from https://www.iom.int/sites/default/files/dtm/IOM-DTM-AFG-Baseline-Assessment-Round2SummaryResults.pdf

64 Ibid.

65 Ibid.

66 Ibid.

67 Ibid.

68 Ibid.

69 Afghanistan Weekly Field Report. Week of 27 November - 3 December 2017, op. cit.

70 Displacement Tracking Matrix (DTM), Afghanistan Baseline Mobility Assessment, op. cit., 3.

71 lbid.

72 Ibid.

73 Afghanistan Weekly Field Report. Week of 27 November - 3 December 2017, op. cit.

74 Labour and Housing Market Systems in Nangarhar Province, Eastern Afghanistan, op. cit., 7.

75 This phrase was used by Laurence Hart, the head of the IOM office in Kabul, as quoted in: R. Nordland (2016, November 4). Afghanistan Itself Is Now Taking In the Most Afghan Migrants. New York Times. Retrieved 8 December 2017, from

https://www.nytimes.com/2016/11/05/world/asia/afghanistan-migrants.html 
(C) Oxfam International January 2018

This report was written by Dr. Jorrit Kamminga and Akram Zaki. Oxfam acknowledges the assistance of Rahim Gul Amin, William Carter, Khadem Hussein Rahimi and Khalid Ahmad Hussaini of the Norwegian Refugee Council (NRC) as well as Samir Ahmad, Anna Chernova, Rajab Faqri, Freshta Ghani, Javlon Hamdamov, Stuart Kent, Robert Lindner, Dr. Naqibullah, Florian Oel, Mohamed Riyas, Evelien van Roemburg, Claire Seaward, Raphael Shilhav, Wahidullah Shinwari, and Tim Zijlstra from Oxfam, in its production.

The authors are indebted to the following organizations for their willingness to take part in the interviews and focus group meetings: The Afghan Development Association (ADA), the Afghanistan Independent Human Rights Commission (AIHRC), the Danish Refugee Council (DRC), the International Organization for Migration (IOM), the Ministry of Refugees and Repatriation (MoRR), NRC, Oxfam, the Peace Training and Research Organization (PTRO), the United Nations Office for the Coordination of Humanitarian Affairs (UN OCHA), the United Nations Refugee Agency (UNHCR), and War Child.

For further information on the issues raised in this report please email advocacy@oxfaminternational.org

This publication is copyright but the text may be used free of charge for the purposes of advocacy, campaigning, education, and research, provided that the source is acknowledged in full. The copyright holder requests that all such use be registered with them for impact assessment purposes. For copying in any other circumstances, or for re-use in other publications, or for translation or adaptation, permission must be secured and a fee may be charged. Email policyandpractice@oxfam.org.uk

The information in this publication is correct at the time of going to press.

Published by Oxfam GB for Oxfam International under ISBN978-1-78748-147-3 in January 2018 DOI: $10.21201 / 2017.1473$

Oxfam GB, Oxfam House, John Smith Drive, Cowley, Oxford, OX4 2JY, UK.

\section{OXFAM}

Oxfam is an international confederation of 20 organizations networked together in more than 90 countries, as part of a global movement for change, to build a future free from the injustice of poverty.

Please write to any of the agencies for further information, or visit www.oxfam.org

Oxfam America (www.oxfamamerica.org)

Oxfam Australia (www.oxfam.org.au)

Oxfam-in-Belgium (www.oxfamsol.be)

Oxfam Brasil (www.oxfam.org.br)

Oxfam Canada (www.oxfam.ca)

Oxfam France (www.oxfamfrance.org)

Oxfam Germany (www.oxfam.de)

Oxfam GB (www.oxfam.org.uk)

Oxfam Hong Kong (www.oxfam.org.hk)

Oxfam IBIS (Denmark) (www.ibis-global.org)
Oxfam India (www.oxfamindia.org)

Oxfam Intermón (Spain) (www.oxfamintermon.org)

Oxfam Ireland (www.oxfamireland.org)

Oxfam Italy (www.oxfamitalia.org)

Oxfam Japan (www.oxfam.jp)

Oxfam Mexico (www.oxfammexico.org)

Oxfam New Zealand (www.oxfam.org.nz)

Oxfam Novib (Netherlands) (www.oxfamnovib.nl)

Oxfam Québec (www.oxfam.qc.ca)

Oxfam South Africa (www.oxfam.org.za) 